\title{
Genetic and Epigenetic Factors Co-Influence the Severity of Phenotypic Presentations in Compound G6PD Mutations
}

\author{
Genetik ve Epigenetik Faktörler Bileşik G6PD Mutasyonlarında Fenotipik Sunumların \\ Ağırlığını Birlikte Etkilerler
}

\author{
(D) Yee Yik Mot¹, (D) Jay Suriar Rajasuriar2, (D) Hafizuddin Mohamed Fauzi1,3, (D) Emmanuel Jairaj Moses 1,3 , (D) Narazah Mohd Yusoff1,3 \\ ${ }^{1}$ Regenerative Medicine Sciences Cluster, Advanced Medical and Dental Institute, Universiti Sains Malaysia, Penang, Malaysia \\ 2Department of Medicine, Gleneagles Hospital Kuala Lumpur, Kuala Lumpur, Malaysia \\ ${ }^{3}$ Clinical Genetics Unit, Advanced Diagnostics Laboratory, Advanced Medical and Dental Institute, Universiti Sains Malaysia, Penang, Malaysia
}

\section{To the Editor,}

Compound mutations in the G6PD gene are rapidly becoming a major concern, especially in highly affected regions where patients may inherit parental alleles both containing mutations $[1,2]$. The loci in which these mutations occur are also important as cis and trans base changes can present vastly differing effects for protein secondary structures [3]. Furthermore, it is challenging to determine disease severity in these patients as enzyme activities and levels cannot be accurately predicted through mutational profiling alone.

The index case presented here was a 30-year-old Chinese woman pregnant with her first child at 13 weeks of gestation and presenting with chronic anemia. She was the youngest of four siblings and was reportedly anemic since the age of 10, predating the onset of menstruation. Her parents were nonconsanguineous.

Her physical examination was unremarkable with no signs of splenomegaly or jaundice. Abnormal results of hematological laboratory investigations were as follows: hemoglobin $10.6 \mathrm{~g} / \mathrm{dL}$ (normal range: $12.0-16.0 \mathrm{~g} / \mathrm{dL}$ ), packed cell volume $33 \%$ (normal: $35 \%-47 \%)$, red blood cell count $3.19 \times 10^{12} / \mathrm{L}\left(3.90-5.60 \times 10^{12} / \mathrm{L}\right)$, mean corpuscular volume $102 \mathrm{fL}$ (76-96 fL), red blood cell distribution width $11.8 \%$ (12.4\%-15.1\%), and reticulocytes 2.7\% (0.2\%-2.0\%). Peripheral blood film revealed the presence of spherocytes and polychromasia. Hereditary spherocytosis or other inherited hemolytic anemia was suspected. Subsequent biochemistry tests indicated that serum ferritin was elevated at $300.5 \mu \mathrm{g} / \mathrm{L}(10.0-291.0 \mu \mathrm{g} / \mathrm{L})$. Iron deficiency anemia was therefore excluded because ferritin was not deficient. An osmotic fragility test was also performed and indicated a right shift suggestive of hereditary spherocytosis. Furthermore, a G6PD assay showed partial enzyme deficiency at $2.12 \mathrm{U} / \mathrm{g} \mathrm{Hb}$ (6.61-11.81 U/g Hb) [4]. Additional evaluations directed toward the diagnosis of warm autoimmune hemolytic anemia indicated that it could be excluded.
The patient's blood sample was subsequently sent for next-generation sequencing (NGS) and analysis. The testing identified two heterozygous missense variants in G6PD: Canton c. 1376G >T, p.(Arg459Leu) and Kaiping c.1388G >A, p.(Arg463His) mutations, both of which have been established as diseasecausing variants. Sequencing data indicated that the variants occurred on different parental copies of the gene (trans). The NGS data did not indicate the presence of other mutations related to spherocytosis.

The combination of Canton and Kaiping mutations has previously been identified in 5 patients in a large-scale G6PD population study with a pattern of consistent severe enzyme deficiency at $0.65 \pm 0.52 \mathrm{U} / \mathrm{g} \mathrm{Hb}$ [2]. In contrast, the patient in our report presented with partial enzyme deficiency of $2.12 \mathrm{U} / \mathrm{g}$ $\mathrm{Hb}$ and experienced only mild chronic anemia. Differences in enzyme levels and clinical presentations could be explained by genomic and epigenetic factors including the location of the mutations and $\mathrm{X}$-inactivation status (Figure 1).

The patient was followed with history and physical examinations being closely monitored and she subsequently delivered a healthy baby boy. The patient was prescribed hematinics during her pregnancy and those were discontinued after an uneventful birth.

In summary, compound heterozygous G6PD mutations do not necessarily lead to severe enzyme activity deficiency and exacerbated clinical symptoms. Therefore, it is recommended that patients at high risk of multiple G6PD mutations undergo NGS analysis to firstly identify the position of the mutations (either cis or in trans) and secondly determine the inactivation status of X-chromosomes to ascertain the dominant red blood cell population. To our knowledge, this is the first report of a pregnancy and delivery with compound heterozygous G6PD mutations and this report therefore contributes to the existing data on clinical observations and genotype-phenotype correlations. These findings will also aid in establishing a risk 


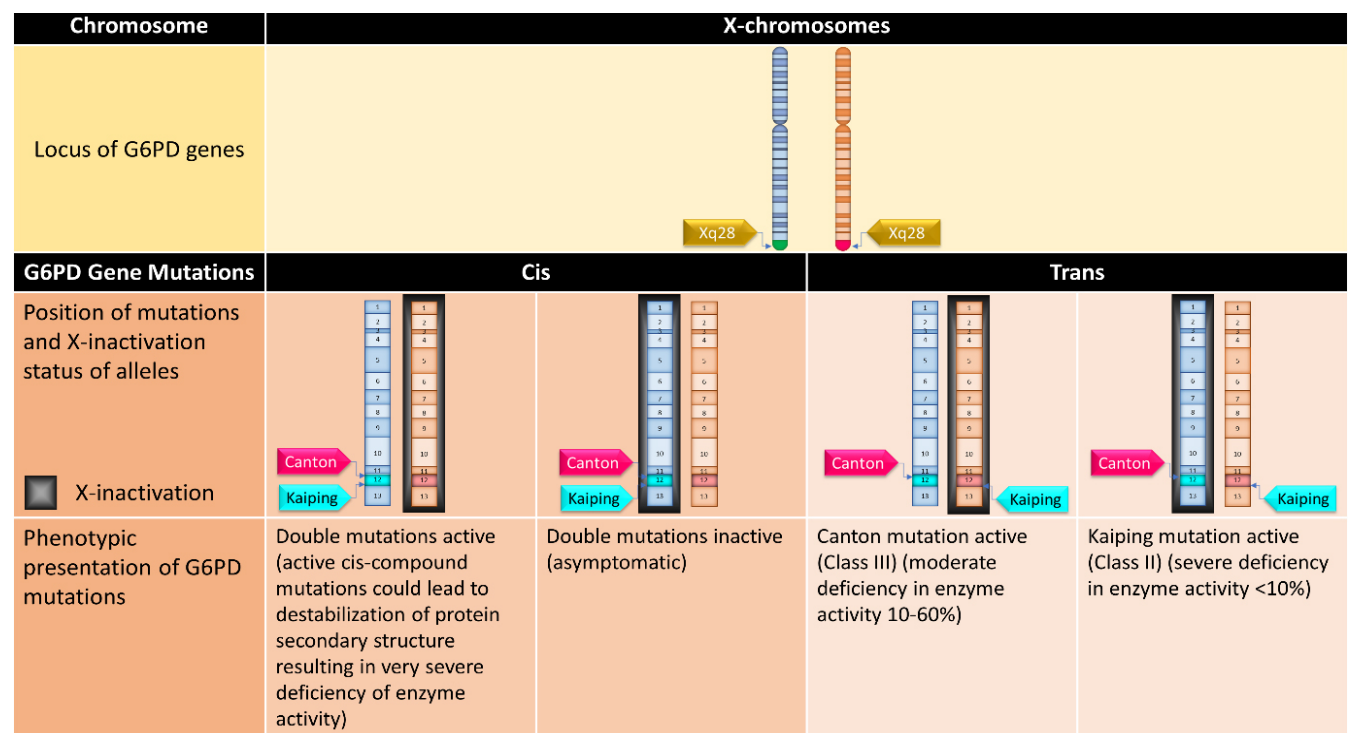

Figure 1. Position of mutations and $\mathrm{X}$-inactivation status is crucial in the determination of G6PD disease phenotype. Cis compound mutations carry a risk of more serious clinical symptoms due to the effects of the double mutations critically destabilizing the protein secondary structure, resulting in a very severe deficiency in enzyme activity. Double trans mutations lead to a presentation of either variant, with less severe clinical manifestations compared to cis mutations. For our patient, it was confirmed that the mutations occurred in trans, rendering a less severe clinical manifestation.

stratification according to the World Health Organization classification [5], which would better inform healthcare providers about disease prognosis and thus enable more comprehensive management strategies for patients.

Keywords: Next-generation sequencing, Compound G6PD mutations, X-inactivation, Chronic anemia

Anahtar Sözcükler: Yeni nesil sekanslama, Bileşik G6PD mutasyonları, X-inaktivasyonu, Kronik anemi

\section{Authorship Contributions}

Surgical and Medical Practices: J.S.R, N.M.Y.; Concept: N.M.Y.; Design: N.M.Y., Y.Y.M.; Data Collection or Processing: J.S.R, N.M.Y.; Analysis or Interpretation: J.S.R, N.M.Y. H.M.F., Y.Y.M., E.J.M.; Literature Search:Y.Y.M., N.M.Y., E.J.M., H.M.F.; Writing: M.Y.Y., N.M.Y., E.J.M., H.M.F.

Conflict of Interest: No conflict of interest was declared by the authors.

Financial Disclosure: The authors declared that this study received no financial support.

\section{References}

1. Liu Z, Yu C, Li Q, Cai R, Qu Y, Wang W, Wang J, Feng J, Zhu W, Ou M, Huang W, Tang D, Guo W, Liu F, Chen Y, Fu L, Zhou Y, Lv W, Zhang H, Zhang J, Wang M, Yang J, Wan K, Miao J, Yuan Z, Liu H, He X, Li W, Chen W, Ye L, Chen Y, Huang $S$, Liu $H$, Ding $H$, Gan $X$, Wang $S$, Qiang $R$, Gong $M$, Teng $P$, Wang $H$, Zhou M, Wei H, Liu X, Tang K, Ma Y, Wu H, Shu X, Chen Y, Zhuang D, Li H, Liu Z, Liu X, Chen Y, Zhu L, Zhu X, Mo C, Tang H, Yin F, Shao Z, Zhang P, Peng $B$, Lu Q, Wang Z, Zou L. Chinese newborn screening for the incidence of G6PD deficiency and variant of G6PD gene from 2013 to 2017. Hum Mutat 2020;41:212-221.

2. He $Y$, Zhang $Y$, Chen $X$, Wang 0 , Ling $L, X u$ Y. Glucose-6-phosphate dehydrogenase deficiency in the Han Chinese population: molecular characterization and genotype-phenotype association throughout an activity distribution. Sci Rep 2020;10:17106.

3. Boonyuen U, Chamchoy K, Swangsri T, Saralamba N, Day NPJ, Imwong $M$. Detailed functional analysis of two clinical glucose-6-phosphate dehydrogenase (G6PD) variants, $\mathrm{G} \mathrm{PD}_{\text {viangchan }}$ and $\mathrm{G} 6 \mathrm{PDV}_{\text {iangchan + Mahidol }}$ : decreased stability and catalytic efficiency contribute to the clinical phenotype. Mol Genet Metab 2016;118:84-91.

4. Azma RZ, Hidayati N, Farisah NR, Hamidah NH, Ainoon O. G6PD enzyme activity in normal term Malaysian neonates and adults using a OSMMR2000-D kit with Hb normalization. Southeast Asian J Trop Med Public Health 2010;41:982-988.

5. WHO Working Group. Glucose-6-phosphate dehydrogenase deficiency. Bull World Health Organ 1989;67:601-611.
Address for Correspondence/Yazışma Adresi: Narazah Mohd Yusoff, M.D., Regenerative Medicine Sciences Cluster, Advanced Medical and Dental Institute, Universiti Sains Malaysia, Penang, Malaysia Phone : +604-5622395

E-mail : narazah@usm.my ORCID: orcid.org/0000-0001-6801-2508
Received/Geliş tarihi: August 3, 2021 Accepted/Kabul tarihi: December 1, 2021

DOI: 10.4274/tjh.galenos.2021.2021.0449 